\title{
KONTRIBUSI GERAKAN NURCU DALAM KEBANGKITAN ISLAM DI TURKI
}

\author{
Akhmad Rizqon Khamami \\ Institut Agama Islam Negeri Tulungagung, Indonesia \\ E-mail: rizqonkham@yahoo.com
}

\begin{abstract}
This paper discusses the contributions of Nurcu movement in strengthening Islam in contemporary Turkey. In consonance with the rise of Turkey as a strong country in political and economical sphere on global level, this country is said to be a symbol of Islamic renaissance of the Muslim world. The four consecutive victories of Erdoğan's party in Turkey's general election are seen as a solely factor for the Islamic renaissance of Turkey. But this article argues that there is yet another Islamic movement which worked on Islamic da'wah far before AKP grabbed the power. Nurcu is of this type. It has a large number of members ranging from businessmen, intellectuals, students, and housewives. The businessmen of Nurcu are known as "Anatolian Tigers" who have contributed to developing economy of Turkey since Turgut Özal opened up liberal economy and integrated its economy into greater lap of the world economy in the 1980s. This development of the Turkey economy goes hand in hand with the spirit of Islamic way of life within Turkish community. This article assumes that the movement has paved the way for AKP's victories; and is currently for Recep Tayyip Erdoğan to receive the tittle of newly-found Islamic hero of the contemporary Islam in the Indonesian political Islamists' view.
\end{abstract}

Keywords: Nurcu; Gülen Movement; Islam in Turkey.

\section{Pendahuluan}

Akhir-akhir ini marak di berbagai media sosial dan media cetak di Indonesia-terutama yang memiliki kecenderungan pada kelompok penganut Islamisme Politik ${ }^{1}$ —negara Turki di bawah pemerintahan

\footnotetext{
${ }^{1}$ Penggunaan istilah "Islamisme Politik" ini mengikuti tulisan Zeynep Akbulut Kuru dan Ahmet T. Kuru untuk menyebutkan sebuah ideologi yang muncul pada abad kedua puluh sebagai reaksi atas kolonialisme dan modernisasi. Islamisme politik memiliki cita-cita membangun sebuah "negara Islam" yang berlandaskan sharî‘ah.
} 
Recep Tayyip Erdoğan dan AKP (Adalet ve Kalkinma Partisi; Partai Keadilan dan Pembangunan) dijadikan referensi yang sering dimunculkan seiring tampilnya Turki sebagai salah satu negara berpengaruh di pentas politik Timur Tengah dan sebagai negara terkaya di dunia nomor $17 .^{2}$ Tidak saja kuat secara ekonomi dan politik, Turki dianggap sebagai simbol kebangkitan Islam berkat kegairahan berislam yang begitu semarak. ${ }^{3}$ Kemenangan AKP selama empat kali berturut-turut sejak 2002 disebut sebagai satu-satunya faktor kebangkitan Islam di Turki tersebut. ${ }^{4}$

Secara garis besar, di tengah panggung politik Turki terdapat dua kekuatan besar, yaitu kelompok sekuler dengan Kemal Atatürk sebagai ideolog utamanya dan kelompok politik Islam Millî Görüş dengan Necmettin Erbakan sebagai penggagasnya. ${ }^{5}$ Namun di luar dua kekuatan tersebut, terdapat kekuatan lain yang memberi pengaruh besar pada kebangkitan Islam di Turki, yaitu gerakan Nurcu yang bergerak dalam bidang dakwah. Penulis berasumsi, berkat gerakan dakwah Nurcu ini semarak berislam di Turki menjadi sebuah fenomena menarik setelah sekian lama Turki mengalami westernisasi di bawah rezim Kemalis. Argumen penulis, kemunculan gerakan dakwah ini justru menjadi kunci kemenangan gerakan Islam politik AKP pimpinan Erdoğan pada pemilihan umum tahun 2002 dan

Lihat Zeynep Akbulut Kuru dan Ahmet T. Kuru, "Apolitical Interpretation of Islam: Said Nursi's Faith-Based Activism in Comparison with Political Islamism and Sufism", Islam and Christian-Muslim Relations, Vol. 19, No. 1 (2008), 100.

2 Menurut data International Monetary Fund (IMF) dan Bank Dunia, pada tahun 2015 Turki menempati urutan 17 sebagai negara dengan ekonomi terbesar di dunia. Lihat https://en.wikipedia.org/wiki/List_of_countries_by_GDP_(PPP); lihat juga, https://knoema.com/nwnfkne/world-gdp-ranking-2015-data-and-charts. Diakses pada 3 Mei 2015.

${ }^{3}$ Nuim Hidayat, "Islamisasi Partai Islam: Pelajaran dari Erdogan", Hidayatullah, 29 Maret 2014.

4 AKP meraih kemenangan selama empat kali berturut-turut: tahun 2002 (34,3\%), 2007 (46,6\%), 2011 (49,8\%) dan Juni 2015 (40,9\%). Hingga tulisan ini diturunkan beredar analisa dari sejumlah pengamat yang memprediksikan Pemilu akan segera diadakan kembali akibat pemenang suara terbanyak (AKP) tidak menemukan partai koalisi yang cocok. Diperkiraan Pemilu ulang akan dilangsungkan pada bulan November 2015 dengan prediksi kemenangan yang lebih besar bagi AKP.

5 Lihat Ahmet Yildiz, "Politico-Religious Discourse of Political Islam in Turkey: The Parties of National Outlook", The Muslim World, Vol. 93 (April 2003), 187-209. Lihat juga Mathew Andrews, "Building Institutional Trust in Germany: Relative Success of the Gülen and Milli Gorus", Turkish Studies, Vol. 12, No. 3 (September 2011), 511-524. 
sebagai penjaga kegairahan berislam di Turki. Kelak pada tahun 2015 Erdoğan tinggal memanen nama besar sebagai sosok pahlawan kebangkitan Islam di mata aktivis dan simpatisan kelompok Islamis Indonesia.

Nurcu adalah salah satu gerakan Islam yang paling tua dalam sejarah Turki modern. Bibit gerakan Nurcu ini mula-mula muncul pada tahun 1930-an. Masa itu, westernisasi di tangan pendiri Turki modern, Mustafa Kemal Atatürk yang "dipaksakan dari atas" mendapat perlawanan ideologis dan kultural. Perlawanan bersenjata dipimpin oleh Shaykh Said al-Kurdi (1865-1925), sementara perlawanan kultural digerakkan oleh Said Nursi (1873-1960). Berbeda dari Shaykh Said al-Kurdi, Nursi memilih berjuang melalui jalur dakwah, kepenulisan dan intelektual. Pengikut Nursi-kebanyakan kalangan bawah dan petani yang kemudian menjadi cikal-bakal gerakan Nurcu-menyebarkan pemikirannya ke seantero negeri. Para pengikut generasi awal ini berasal dari masyarakat pedesaan. Saat itu jumlah mereka terbilang masih sedikit. Para pengikut pemikiran Nursi-yang dikenal dengan istilah Nurculuk-berubah menjadi gerakan sosial di kemudian hari. Mereka tidak melakukan penentangan secara frontal melawan rezim sekuler Kemalis, namun menjalankan perlawanan kultural.

\section{Said Nursi dan Kelahiran Gerakan Nurcu}

Pendiri gerakan Nurcu adalah Bediüzzaman Said Nursi. Ia lahir pada tahun 1876 di Nurs, propinsi Bitlis, Anatolia. ${ }^{6}$ Ayahnya adalah seorang molla, atau pemuka agama. Bitlis merupakan tempat berdiamnya populasi suku Kurdi, Kristen Armenia, dan pengikut tasawuf. Pendidikan awal Nursi diperoleh dari sejumlah tokoh tarekat Naqshabandîyah. ${ }^{7}$ Ia belajar di berbagai madrasah di kota

\footnotetext{
${ }^{6}$ Ada beberapa versi tentang tahun lahir Said Nursi. Perbedaan ini muncul karena persoalan konversi penanggalan antara dua sistem kalender yang dipakai di Kesultanan Ottoman: Hicri (sistem kalender Islam berbasis rembulan untuk urusan keagamaan) dan Rumi (sistem kalender berbasis matahari versi Ottoman untuk urusan administratif dan ekonomi). Selain itu, kemudian sistem kalender Miladi (Gregorian) digunakan secara nasional di Republik Turki sejak 1926. Karena itu Serif Mardin berpendapat bahwa Nursi lahir pada tahun 1873, Sahiner pada 1876, dan Mustofa Gokhan Sahin pada 1878. Penulis melihat pendapat Sahiner sebagai pendapat yang lebih kuat.

7 Sukran Vahide, "Toward an Intellectual Biography of Said Nursi", dalam Ibrahim M. Abu Rabi (ed.), Islam at the Crossroads: On the Thought and Life of Bediuzzaman Said Nursi (Albany: State University of New York Press, 2003), 4.
} 
kelahirannya. Berulang-kali ia berpindah madrasah meski belum menggenapkan masa belajarnya. Dugaan penulis, tindakan tersebut dipicu oleh cara pandang Nursi yang melihat sistem pendidikan madrasah masa itu tidak cukup memuaskan dahaga intelektualnya. Nursi adalah pelahap buku yang serius. Waktu luangnya diisi dengan membaca. Ia merupakan tipologi otodidak. Hanya dalam jangka enam bulan, misalnya, Nursi mampu menyelesaikan pelajaran yang biasanya dikuasai seseorang setelah menempuh masa belajar lima belas hingga dua puluh tahun. Padahal saat itu usianya masih belia. Tidak mengherankan jika julukan molla ia sandang pada umur 14. Sejak itu Nursi mulai ikut serta dalam pertemuan tokoh agama di daerahnya. Ia sering terlibat dalam perdebatan soal agama dengan para pemuka Islam yang jauh lebih tua. ${ }^{8}$ Seringkali ia memenangi perdebatan ini. Salah satu kuncinya adalah penguasaan bahasa Arab yang matang.

Kesuksesan dalam berbagai debat, serta sikapnya yang tidak biasa—seperti selalu memakai turban dan jubah—menarik perhatian Hasan Pasa, gubernur Bitlis masa itu. Sang Gubernur membawa serta Nursi ke kediamannya. Nursi menghabiskan dua tahun di kediaman Sang Gubernur, 1892-1894. Melalui buku dan majalah populer yang tersedia di perpustakaan pribadi Gubernur, Nursi berkenalan dengan pemikiran modern dari Barat. Masa itu usia Nursi menjelang 20 tahun-masa-masa puber-dan Sang Gubernur memiliki tiga putri jelita, namun ia tidak menaruh perhatian kepada mereka. Alasannya, "demi menjaga kemuliaan menuntun ilmu, saya tidak dibenarkan untuk menatap mereka". ${ }^{10}$ Selanjutnya, pada tahun 1894 ia berpindah ke Van, dan tinggal di sana hingga 1907. Kedekatan Nursi dengan gubernur Van, Tahsin Pasa, memberinya akses untuk masuk ke dalam lingkaran pergaulan kalangan ulama dan suku Kurdi di wilayah tersebut. $^{11}$

Pengalaman selama di Bitlis dan Van menyadarkan Nursi bahwa ada yang salah dengan kondisi di wilayah tersebut, yaitu kurangnya pendidikan. Akhirnya, Nursi memunculkan ide pendirian sebuah

\footnotetext{
${ }^{8}$ Serif Mardin, Religion and Social Change in Modern Turkey: The Case of Bediuzzaman Said Nursi (Albany: SUNNI Press, 1989), 71.

9 Vahide, "Toward an Intellectual Biography", 4.

${ }^{10}$ Sukran Vahide, "The Life and Times of Bediuzzaman Said Nursi", The Muslim World, Vol. LXXXIX, No. 3-4 (1999), 2012.

11 Vahide, "Toward an Intellectual Biography", 27.
} 
madrasah modern di Anatolia dengan nama Medreset-ür. Zehra. ${ }^{12}$ Rencananya, sekolah ini akan mengajarkan ilmu pengetahuan Barat berdampingan dengan ilmu agama. Nursi sangat antusias dengan rencana tersebut. Untuk merealisir mimpinya ia mencari dukungan dana dari Sultan Abdul Hamid II. Tahun 1907 ia berangkat ke Istanbul.

Sesampai di Istanbul Nursi mengajukan permohonan dana kepada Sultan Abdul Hamid II. Selain permintaan bantuan dana, ia juga mengajukan permohonan izin agar bahasa pengantar pendidikan di madrasah tersebut kelak menggunakan bahasa Kurdi di samping bahasa Turki. Namun, seluruh permintaannya ditolak. Penolakan ini, menurut satu versi, konon disebabkan karena Nursi tidak menghadap langsung kepada Sultan. Permohonannya disampaikan melalui gubernur Van. Versi lain menyebutkan bahwa Nursi benar-benar bertemu dengan Sultan berkat jasa Sang Gubernur. Bahkan diceritakan dalam satu kisah, selama bertemu Abdul Hamid II, sikap Nursi dan cara berbicaranya yang udik membuat marah Sultan. Perlu kita ketahui bahwa sebagai seseorang yang bersuku Kurdi, Nursi belajar bahasa Turki pada usia 20-an sebagai bahasa keempat yang ia kuasai selain Kurdi, Arab dan Persia. Kemarahan Sultan menjadikan Nursi dituduh tidak waras. Nursi lantas dikirim ke rumah sakit jiwa untuk diperiksa. Setelah dinyatakan tidak mengalami gangguan mental, Abdul Hamid II menawari bayaran tinggi kepada Nursi untuk bekerja di Yildiz Palace. Tawaran ini barangkali merupakan kompensasi Sultan atas kesalahannya. Namun Nursi menolak.

Selama menetap di Istanbul, Nursi juga membangun kontak dengan lingkaran intelektual Ibu Kota. Bersama kelompok Turki Muda ia melancarkan oposisi politik menentang Sultan Abdul Hamid II. Sultan bereaksi. Dengan disokong sejumlah tokoh agama dan siswa-siswa madrasah, Sultan Abdul Hamid II melancarkan serangan balasan melawan Turki Muda pada tahun 1908. Reaksi ini dikenal sebagai "serangan balas 31 Maret". Aksi serangan balasan ini gagal, lalu terjadi penangkapan besar-besaran. Nursi adalah salah satu dari mereka yang dibawa ke pengadilan pada 1909 meskipun jelas-jelas ia pendukung pemerintahan Turki Muda. Penangkapan ini barangkali karena Nursi sebagai tokoh agama dianggap terlibat bersama-sama

12 Pilihan nama Medreset-üz Zehra ini, di mata sebagian ilmuwan karena Nursi terilhami Universitas al-Azhar di Kairo, Mesir. Lihat Mardin, Religion and Social Change, 80. 
dengan tokoh agamawan lain. Pengadilan akhirnya melepaskan Nursi setelah ia menyampaikan pembelaan diri. Pledoi ini kemudian diterbitkan dengan judul Divan-i Harb-i Orfi. Selanjutnya, Turki Muda dan organisasinya, Commitee of Union and Progress (CUP), menjadikan "serangan balas 31 Maret" sebagai alasan untuk melengserkan Abdul Hamid II dan menggantikannya dengan Sultan Mehmed V Resad (berkuasa 1909-1918).

Pada tahun 1911 Sultan Mehmed V Resad mengundang Nursi untuk mengadakan perbincangan dua mata. Nursi adalah penyokong kuat konstitusi 1908 yang dicanangkan Turki Muda. Nursi dikirim ke wilayah Anatolia di tengah suku Kurdi sebagai utusan negara untuk meyakinkan rakyat di wilayah tersebut tentang manfaat konstitusi 1908 dan persesuaiannya dengan sharî́ah Islam. Selama rentang tahun 1910 hingga 1914, ia berkeliling di Anatolia untuk menyebarkan propaganda tersebut. Bahkan pada tahun 1911 Nursi menemani kunjungan Sultan Resad ke Balkan. Kunjungan ini dimaksudkan untuk meredam pergolakan sosial selepas pemberontakan Albania yang meletus setahun sebelumnya akibat kemunculan semangat nasionalisme di wilayah tersebut. ${ }^{13}$

Nursi meyakinkan Sultan Mehmed V Resad tentang pentingnya pendidikan di Anatolia. Setelah mendapat persetujuan dan janji finansial dari Sultan, Nursi kembali ke Van untuk mencari tempat yang cocok bagi pendirian madrasah. Karena berkecamuk perang Balkan dan negara mengalami kesulitan finansial, proyek tersebut batal terrealisasi. Perang Dunia Pertama tahun 1914 memperparah kondisi ekonomi negara. Mimpi Nursi buyar.

Saat berkecamuk Perang Dunia Pertama, Nursi ikut bertempur melawan Rusia. Ia tertangkap dan menjadi tawanan perang pada 1916. Ia dipenjarakan di Siberia. Selama di penjara, kegelisahan Nursi mulai muncul. Setelah menghabiskan separuh hidupnya dalam kegiatan politik, demikian renungan Nursi, ternyata dunia politik tidak memberinya kepuasan batin. Setelah melepaskan diri dari penjara tahun 1918 dengan memanfaatkan situasi huru-hara revolusi Bolshevik di Rusia, ia kembali ke Istanbul melalui jalur Eropa. Tak lama kemudian ia diangkat sebagai pejabat di Dar-ul bikmet-i Islamiyye, sebuah lembaga untuk membantu pemerintah dalam urusan agama.

Di lembaga keagamaan ini Nursi menyokong Mustafa Kemal dalam pembebasan Turki dari tangan penjajah. Ia memberi dukungan

${ }^{13}$ Vahide, “Toward an Intellectual Biography”, 101. 
penuh kepadanya saat berperang melawan pasukan Yunani. Pada saat Shaykh al-Islâm mengeluarkan fatwa menentang Mustafa Kemal, Nursi justru menuduh fatwa Shaykh al-Islâm tidak sah karena dikeluarkan di bawah tekanan pasukan Sekutu. Seusai perang, Kemal mengundang Nursi untuk hadir dalam sidang anggota parlemen Turki. Nursi menerima dengan senang hati. Ketika hadir, ia kecewa dengan sikap apatis mayoritas anggota parlemen Republik Turki yang tidak hirau terhadap agama. Ia menolak tawaran Kemal untuk bergabung dalam parlemen. Nursi melihat jalan pikiran Kemal berbeda dari dirinya, dan negara Turki dibangun jauh dari semangat Islam.

Kekecewaan itu memicu kemunculan kembali kegelisahan Nursi yang terpendam selama beberapa saat. Ketika kegelisahannya memuncak, Nursi mengalami depresi dan krisis diri. Beruntung, di saat krisis ini muncul, ia membaca buku Futûh al-Ghayb karya Shaykh 'Abd al-Qâdir al-Jîlânî (w. 1166). Buku ini membuatnya semakin yakin untuk mengundurkan diri dari arena politik dan mengabdikan diri sepenuhnya untuk al-Qur'ân. Ia meninggalkan Ankara; berangkat menuju Van. Di tempat ini ia hidup menyendiri untuk mendalami alQur'ân.

Pada tahun 1925, bersama sejumlah tokoh Kurdi lainnya, Nursi dituduh terlibat dalam pemberontakan Shaykh Said al-Kurdi. Tuduhan tersebut tidak memiliki dasar. Meskipun sama-sama bersuku Kurdi, sesungguhnya pemberontakan ini dipimpin oleh seorang tokoh tarekat Naqshabandîyah bernama Shaykh Said al-Kurdi. ${ }^{14}$ Meskipun kedua orang ini tidak ada kaitan sama sekali, Nursi ditangkap dan diperlakukan secara brutal. Perlakuan brutal pemerintah Ankara memaksanya mengungsi. Kemudian ia menetap di Barla, Isparta. Perlakuan brutal tersebut semakin memantapkan suara hatinya untuk tidak lagi terjun ke kancah politik.

Nursi merasa bahwa problem yang menimpa masyarakat Turki sesungguhnya berada di wilayah kultural-yaitu dampak dari westernisasi. Tersebarnya filsafat meterialisme menjadi ancaman serius bagi keimanan seorang Muslim. Ancaman ini lebih berbahaya dibanding ancaman politik dari Barat. Ancaman Barat mudah dideteksi dan bisa dilawan, sedangkan ancaman yang menyerang iman datang dari dalam. Ibaratnya, cacing pembawa penyakit sudah berdiam di dalam badan, dan untuk mengalahkannya butuh kerja yang

14 Lihat Robert Olson, The Emergence of Kurdish Nationalism and the Sheikh Said Rebellion: 1880-1925 (Austin: University of Texas Press, 1989). 
sangat keras. Nursi menyadari, ia harus melakukan sesuatu untuk menyelamatkan iman orang-orang Islam. Karena itu ia memfokuskan diri pada upaya penyelamatan iman ini. ${ }^{15}$ Sejak saat itu perubahan cara pandang terjadi pada diri Nursi dari old Said (Said lama) menjadi new Said (Said baru). ${ }^{16}$

Fase "old Said" adalah masa pada saat Nursi berperan sebagai seorang aktivis yang meyakini bahwa perubahan sosial dapat dilakukan melalui jalur politik, sedangkan "new Said" adalah masa di mana Nursi meyakini transformasi sosial dapat terwujud dengan pembentukan generasi Muslim baru yang mampu berdamai dengan modernitas tanpa harus mengorbankan identitas keislamannya. Ia memutuskan untuk tidak lagi berkecimpung di dunia politik praktis. Ia bertekad, sisa hidupnya dihabiskan untuk berjuang membangun generasi baru Muslim lewat dakwah dan pembentukan akhlaq. Ungkapan Nursi yang terkenal: a ûdh bi Allâh min al-shaytân wa al-siyâsah (aku berlindung dari setan dan politik). ${ }^{17}$

Nursi memberi tiga alasan kenapa ia memilih untuk menjauhi dunia politik praktis ini. Pertama, problem utama yang dihadapi umat Islam pada abad 20 adalah melemahnya iman seseorang. Seorang Muslim harus membenahi diri sendiri dari beriman secara taklid (taklidi iman) menjadi iman sejati (tabkiki iman). Di dunia modern, orang Islam menghadapi bahaya ateisme dan materialisme. Iman setiap orang harus diperkuat untuk menahan ancaman ini. Ia bisa menjadi seorang Muslim yang baik tanpa harus negara yang ditempatinya menerapkan hukum Islam. Kedua, Nursi menegaskan bahwa spiritualitas dan dunia politik jarang bisa ketemu. Politik yang cenderung korup, berkonflik dan arogan bertentangan dengan ajaran tentang kemanusiaan, persaudaraan dan kehormatan umat manusia. Ketiga, seandainya Nursi berkecimpung di dunia politik, masyarakat

15 Zeynep Akbulut Kuru dan Ahmet T. Kuru, “Apolitical Interpretation of Islam”, 102.

16 Sebagai bahan perbandingan dalam klasifikasi fase kehidupan Said Nursi, Sujiat Zubaidi membagi tiga fase: Nursi Harakiy, Nursi Tarbawiy dan Nursi al-Zabid. Lihat Sujiat Zubaidi, "Tafsir Kontemporer Bediuzzaman Said Nursi dalam Risale-i Nur, Studi Konstruk Epistemologi” (Disertasi--UIN Sunan Ampel Surabaya, 2015), 138148.

${ }^{17}$ Lihat Colin Turner, "I Seek Refuge in God from Satan and politics..." A Nursian Perspective on the Role of Religion in State and Society", Bediuzzaman Said Nursi, t.th., http://www.bediuzzamansaidnursi.org/en/icerik/i-seek-refuge-god-satanand-politics-nursian-perspective-role-religion-state-and-society. Diakses tanggal 22 April 2015. 
bisa saja salah memahami sesuatu yang ia maksud. Mayoritas masyarakat Turki, demikian Nursi berpendapat, masuk kategori masyarakat yang masih memerlukan bimbingan untuk bisa menemukan jalan kebenaran-yaitu Islam. Seorang pelayan al-Qur'ân (pendakwah) memerlukan kepercayaan masyarakat agar masyarakat mengikuti ajaran al-Qur'ân dengan penuh kecintaan. Dakwah harus berisi murni materi dakwah, tanpa embel-embel politik. Kebenaran alQur'ân diibaratkan sebagai permata, demikian ujar Nursi. Jika dicemari oleh politik-masyarakat awam yang mudah terpedayaakan bertanya-tanya: apakah permata tersebut dijadikan propaganda politik untuk menarik massa? Jika memasuki dunia politik, maka akan menurunkan nilai permata tersebut. Karena itu, seorang pelayan alQur'ân yang baik hendaknya menghindarkan diri politik agar bisa mendapat kepercayaan masyarakat. ${ }^{18}$

Meskipun di mata sebagian ilmuwan perubahan dari "old Said" menjadi "new Said" dianggap sebagai perubahan drastis keengganan Nursi memasuki dunia politik, namun sesungguhnya Nursi bukan sama sekali tidak meninggalkan dunia politik. Menurut hemat penulis, Nursi terlibat dalam dunia politik dengan bentuk yang berbeda, yaitu politik kultural. Di sini Nursi memainkan politik tingkat tinggi. Gaya politik ini dengan sadar ingin membangun perlawanan kultural. Selain itu, alasan Nursi menjauh dari dunia politik, menurut hemat penulis, karena kondisi politik yang ada pada masa itu: Turki memberlakukan sistem partai tunggal, dengan Republican People's Party (RPP) sebagai satu-satunya partai kendaraan bagi penguasa Kemalis. Nursi menyadari konsekuensi negatif yang bisa saja ia terima jika ia memaksakan diri terjun ke dunia politik praktis di saat iklim politik di Turki masih seperti itu. Terbukti berulang kali ia ditangkap dan dibuang ke beberapa tempat, antara lain Isparta (1934), Eskisehir (1935), Kastamonu (1936), Denizli (1943), dan Emirdag (1944). ${ }^{19}$

Sikap Nursi menolak terjun ke dunia politik praktis bukan berarti ia sama sekali menjauhkan diri dari isu-isu sosial politik. Kelak ketika Turki memasuki sistem multipartai, Nursi secara terang-terangan mendukung Democratic Party (DP) pimpinan Adnan Menderes yang berhasil menumbangkan partai Republican People's Party (RPP) yang

18 Zeynep A. Kuru dan Ahmet T. Kuru, “Apolitical Interpretation of Islam”, 102103.

19 Mardin, Religion and Social Change, 90-102. Lihat juga Vahide, "The Life and Times", 208-244. 
telah berkuasa selama tiga dasawarsa. Dukungan ini ia berikan karena DP lebih bersimpati pada kebebasan beragama dibanding RPP. Ia berkirim surat kepada Adnan Menderes, Perdana Menteri kala itu, untuk semakin memperluas ruang kebebasan beragama. Nursi tidak melarang muridnya menjadi anggota DP. Pesan Nursi, asalkan ia melibatkan diri dalam dunia politik sebagai dirinya sendiri, bukan atas nama gerakan Nurcu maupun atas nama Islam. Barang siapa menggunakan Islam untuk urusan politik berarti ia membatasi Islam hanya untuk partainya. Islam bukan milik satu golongan, karena itu Islam tidak boleh dimonopoli oleh satu partai. ${ }^{20}$ Bahkan konon Nursi berkirim surat beberapa kali kepada Adnan Menderes, dan menyebutnya sebagai "pejuang Islam". ${ }^{21}$

Menariknya, Nursi tetap mempercayai keunggulan konstitusi dan demokrasi dibanding dengan bentuk pemerintahan model lain karena bentuk pemerintahan seperti ini, dalam pandangannya, merefleksikan spirit Islam. Meskipun begitu, Nursi menentang adopsi kultur dari Eropa yang bertentangan dengan ajaran Islam. Nursi mewanti-wanti untuk tidak mengambil hal-hal buruk dari peradaban Eropa. Umat Islam hendaknya mengambil hal-hal baik saja. Ia membuat batas antara aspek 'spiritual' dan 'material' peradaban Eropa. Aspek 'material' meliputi sains, teknologi dan pemerintahan berkonstitusi, sedangkan aspek 'spiritual' meliputi agama, etika, moral dan perilaku antarpersonal (khususnya hubungan antara laki-laki dan perempuan). Nursi yakin bahwa modernisasi diperlukan umat Islam untuk bisa menyusul Barat. Islam harus menyesuaikan diri dengan kondisi modern, namun modernisasi tersebut harus sesuai dengan ajaran Islam. Sedangkan westernisasi, bagi Nursi, akan menghasilkan hilangnya nilai-nilai sosial dan degradasi budaya seiring terpinggirkannya agama dari kehidupan publik serta maraknya filsafat materialisme yang leluasa menyerang sendi-sendi agama. ${ }^{22}$

\section{Nurcu sebagai Gerakan Dakwah dan Kultural}

Semasa Nursi masih hidup belum muncul organisasi Nurcu yang signifikan. Pada mulanya Nursi hanya memiliki 13 murid saja. Lalu Risale-i Nur tersebar di kalangan petani, pedagang kecil, pengrajin dan

\footnotetext{
20 Zeynep A. Kuru dan Ahmet T. Kuru, “Apolitical Interpretation of Islam”, 104.

21 Hamid Algar, "Said Nursi and the Risale-i Nur. An Aspect of Islam in Contemporary Turkey". Islamic Perspective-Studies in Honor of Sayyid Abul Ala Mawdudi (Leicester: t.tp., 1979), 323.

22 Mardin, Religion and Social Change, 61.
} 
rakyat jelata. ${ }^{23}$ Dakwah Nursi pada mulanya memfokuskan diri pada pembentukan sosok Muslim yang kokoh. Fokus Nursi pada pengembangan individu ini bahkan menyita perhatian Nursi sehingga ia tidak sempat mendirikan sebuah organisasi massa. Apalagi pada masa itu tidak mungkin bagi Nursi untuk mendirikan sebuah organisasi karena pengikut Nursi masih berjumlah sedikit sehingga kebutuhan akan sumber daya sulit terpenuhi. Beberapa tahun kemudian, sepeninggal Nursi pada tahun 1960, gerakan Nurcu berkembang pesat, tidak saja di pedesaan, tetapi juga berkembang di perkotaan.

Memasuki tahun 1980-an, gerakan Nurcu mengalami transformasi besar, keanggotaannya melebar hingga meliputi para pembisnis, pelajar dan kaum intelektual. Gerakan Nurcu merupakan salah satu gerakan dakwah Islam di Turki yang sangat dinamis, berkembang pesat, tertata dengan baik dan memiliki struktur gerakan yang cukup kuat. Dalam waktu relatif singkat gerakan ini menyebar ke seluruh dunia, bahkan tidak terkecuali Indonesia. Saat ini Nurcu membuktikan diri sebagai sebuah gerakan yang kokoh. Pertanyaan yang muncul adalah bagaimana Nurcu mendapatkan dukungan besar dari masyarakat luas?

Untuk menjawab pertanyaan ini para ilmuwan memunculkan dua pendekatan. Pertama, cara baca dengan menggunakan pendekatan statecentered. Cara pandang ini menyatakan bahwa Kemal Atatürk sama sekali tidak pernah berniat menghapus Islam di Turki. Bahkan Bernard Lewis berpendapat bahwa Atatürk sama sekali tidak menentang agama, irreligion. ${ }^{24}$ Justru sebaliknya, Atatürk melakukan nasionalisasi Islam dengan menjadikan agama ini lebih berwarna lokal yang dikenal dengan istilah Turkish Islam (Islam dengan warna budaya Turki yang kental). ${ }^{25}$ Karena sadar posisi Islam berakar kokoh di tengah masyarakat, sejak 1960-an rezim Kemalis memberi ruang

\footnotetext{
${ }^{23}$ Vahide, "Toward an Intellectual Biography”, 156.

${ }^{24}$ Bernard Lewis, The Emergence of Modern Turkey (London: Oxford University Press, 1961), 412.

25 Untuk membaca keberadaan Islam yang tetap bertahan hidup di tengah proyek westernisasi Atatürk di Turki, Berna Arslan memunculkan dua tesis, yaitu: oppression thesis dan control account thesis. Dalam kedua tesis ini, singkatnya, Islam tidak dihapus, tapi dibiarkan hidup selama bersifat apolitik dan membawa bendera nasionalisme, atau dalam istilah lain sebagai "Turkish Islam". Lihat Berna Arslan, "Pious Science: The Gülen Community and the Making of a Conservative Modernity in Turkey" (Disertasi--the University of California, Santa Cruz, 2009), 156-162.
} 
toleransi yang lebih luas terhadap Islam. Pada tahun 1980-an Turgut Özal memanfaatkan popularitas gerakan Islam untuk menahan laju pertumbuhan gerakan komunis. ${ }^{26}$ Sejak saat itu kegairahan berislam semakin semarak. Gerakan dakwah Islam menemukan momentum untuk berkembang pesat.

Kedua, memakai pendekatan society-centered. Pendekatan ini menempatkan warisan kultur Ottoman sebagai batu pijakan dalam membaca fenomena gerakan Islam di Turki. Selama ratusan tahun, demikian pendekatan ini menyatakan, warisan Ottoman berakar kuat dalam kehidupan masyarakat Turki. Bahkan revolusi Kemalis tidak mampu mengubah pengaruh tersebut meski segala upaya telah diusahakan. Apa pasal? Strategi yang dipakai Atatürk dalam proyek westernisasi tidak menyesuaikan diri dengan budaya masyarakat yang sudah mengakar selama ratusan tahun. Kemalis, demikian tegas Serif Mardin, menggunakan kosa-kata yang sama sekali asing di telinga masyarakat. Meskipun Kemal Atatürk sukses merubah negara Turki menjadi sekuler, lanjut Mardin, pada dasarnya ia gagal mengubah masyarakat. $^{27}$ Kegagalan Kemal Atatürk ini membuka celah munculnya gerakan perlawanan kultural menentang hegemoni rezim Kemalis. Tokoh sentral perlawanan tersebut adalah Nursi. Gerakan Nurcu sukses mendulang dukungan luas berkat kepiwaiannnya menggunakan bahasa keseharian masyarakat, yaitu kultur Islam.

Lewat jalur kultural ini Nursi ingin mengurai kembali hubungan Islam dan modernitas. Ia membangun perjuangan kultural lewat karya-karyanya. Salah satu karya magnum opus-nya adalah Risale-i Nur. Nursi menulis buku ini dalam rentang masa tahun 1925 hingga 1934. Buku Risale-i Nur ditulis dalam bahasa Turki versi Ottoman dengan alfabet Arab, diperbanyak dengan cara manual-ditulis tangan-dan disebarkan secara diam-diam oleh para pengikut Nursi. Baru pada tahun 1950-an saat Turki memasuki era multi-partai, buku ini dicetak dengan menggunakan tulisan Latin. Meskipun tidak dijual bebas karena sensor ketat dari negara, melalui mesin cetak ini Risale-i Nur diperbanyak dalam jumlah besar. Nursi meminta pengikutnya untuk menyebarkan Risale-i Nur di kalangan mahasiswa di Istanbul dan

26 Lihat Umit Cizre Sakallioglu, "Parameters and Strategies of Islam-State Interaction in Republican Turkey", International Journal of Middle Eastern Studies, 28 (1996), 231-251.

${ }^{27}$ Mardin, Religion and Social Change, 3-26. 
Ankara sebagai cara untuk mengurangi penolakan terhadap buku ini dan merekrut kader-kader baru dari kalangan muda. ${ }^{28}$

Hal menarik dari penyebaran Risale-i Nur ini adalah meningkatnya literasi masyarakat awam. Risale-i Nur mendorong masyarakat untuk membaca. Karena hanya dengan membaca seseorang bisa mengetahui isinya. Pada masa itu masyarakat awam masih bergantung pada tradisi oral, bukan tradisi membaca. Masyarakat mengandalkan ceramah dan pengajian umum oleh imam dan ulama. Tidak berlebihan jika Hakan Yavuz menyebut gerakan Nurcu sebagai komunitas tekstual. ${ }^{29}$ Kunjungan penulis ke komunitas Nurcu memperkuat pendapat Yavuz tersebut. Setiap hari pengikut Nurcu akan membaca buku Risale-i Nur sebelum memulai kegiatan harian.

Risale-i Nur berisi penafsiran terhadap al-Qur'ân. Penafsiran ini, menurut Algar, bukan penafsiran yang sistematis. ${ }^{30}$ Ia menafsirkan alQur'ân berdasarkan tema. Selain itu, dalam buku Risale-i Nur, Nursi menulis beragam topik pembahasan, misalnya sekularisme, nasionalisme, dan hubungan antara sains dan agama. Menariknya, kita tidak mendapati tulisan Nursi secara detil berbicara tentang sistem politik Islam ataupun sistem ekonomi Islam. Keengganan membahas politik dan ekonomi Islam ini dapat kita baca sebagai keyakinan Nursi bahwa tidak ada sistem ekonomi dan politik Islam sebagaimana diyakini kelompok Islam revivalis. Nursi, demikian ungkap Hamid Algar, menghindarkan diri dari pembahasan tentang ekonomi dan politik Islam karena ia tidak pernah berniat menggantikan konstitusi sekuler. ${ }^{31}$ Fokus Nursi adalah menyelesaikan problem umat Islam melalui penguatan iman.

Buku Risale-i Nur merupakan faktor paling penting yang melatari ketertarikan seseorang masuk menjadi bagian dari gerakan dakwah Nurcu. Buku ini dirasa memberi kepuasan intelektual dan spiritual di tengah dahaga keagamaan. Berbeda dari kelompok Islam lain, pemikiran Nurcu tidak saja menyerap nilai Islam, tetapi juga mengharmoniskannya dengan sains modern. Risale-i Nur dianggap mampu mensintesiskan agama dengan sains modern. Berkat buku Risale-i Nur ini, tradisi membaca terbentuk di kalangan Nurcu. Dibanding dengan tradisi tasawuf yang lebih bersifat oral dengan

\footnotetext{
28 Algar, "Said Nursi", 323.

${ }^{29}$ M. Hakan Yavuz, "Towards an Islamic Liberalism?: The Nurcu Movement and Fethullah Gülen”, Middle East Journal, Vol. 53, No. 4 (1999), 590.

30 Algar, "Said Nursi", 325.

${ }^{31}$ Ibid., 330.
} 
posisi dominan seorang guru mursyid dalam menciptakan wacana dan pemberian wejangan yang tidak membuka ruang untuk mempertanyakannya, kalangan Nurcu menggantungkan diri pada bacaan Risale-i Nur. Dengan membaca buku tersebut mereka bebas mengembangkan penafsiran atas bacaan tersebut. Seseorang bisa dengan leluasa mempertanyakan sesuatu yang dirasa perlu pendalaman. Selain itu, berkat buku Risale-i Nur, tradisi intelektual yang muncul dalam gerakan Nurcu adalah kemampuan analisa. ${ }^{32}$

Selain dakwah, gerakan Nurcu bergerak dalam bidang sosial. Faktor ini yang membedakan gerakan Nurcu dari dua gerakan Islam lainnya, yaitu gerakan Islamisme politik dan gerakan tarekat sufi. Konsep yang sering digunakan oleh Nursi adalah "aksi positif". ${ }^{33}$ Gerakan Nurcu masuk dalam kategori "aktivisme berbasis iman" (bizmet-i imaniye atau iman hizmeti). ${ }^{34}$ Semangat yang muncul di tengah gerakan Nurcu adalah semangat pelayanan (bizmet) kepada orang lain, termasuk kepada umat manusia di muka bumi ini. Bahkan kelompok Gülen tidak mau gerakan mereka disebut dengan nama Gülen Movement sebagaimana dikenal di kalangan akademisi Barat selama ini. Mereka lebih suka menyebut diri mereka sendiri sebagai gerakan birmet.

Dakwah gerakan Nurcu menitik-beratkan pada dunia jurnalistik. Pada tahun 1964, pengikut Nursi menerbitkan majalah "Hareket", lalu disusul "Zulfikar" di Izmir dan "Bediuzzaman" di Konya. Pada tahun 1968 terbit majalah "Ittihad" di Istanbul. Berkat keberadaannya di kota besar ini "Ittihad" menjadi majalah pertama yang beroplah dengan skala nasional. Pada tahun 1970, majalah ini berubah menjadi koran harian. "Ittihad" selanjutnya berganti nama dengan "Yeni Asya" yang kemudian menjadi nama salah satu kelompok Nurcu. ${ }^{35}$ Tidak kurang dari 15 majalah Nurcu terbit. Dua koran besar muncul dari dua kelompok Nurcu yang berbeda: "Yeni Asya" milik kelompok Yeni Asya, sedangkan “Zaman” milik Gülen Movement. ${ }^{36}$ Menurut

\footnotetext{
32 Ibid., 220.

33 Ibid., 224.

34 Zeynep A. Kuru dan Ahmet T. Kuru, “Apolitical Interpretation of Islam”, 100.

35 Algar, "Said Nursi", 325.

36 Menurut Hakan Yavuz, gerakan Nurcu terfragmentasi menjadi tujuh cabang gerakan, yaitu: Kurdoglu Cemaati, Mehmet Kirkinci, Mustafa Sungur, Yeni Nesil, Yeni Asya, Med-Zehra dan Gülen Movement. Lihat Hakan Yavuz, "The Gülen Movement: The Turkish puritans" dalam Hakan Yavuz and John L. Esposito (eds.)
} 
catatan Medyatava, sebuah lembaga survei tentang sirkulasi penerbitan, oplah koran "Zaman" menembus angka satu juta eksemplar pada bulan Januari 2014. ${ }^{37}$ Koran "Today's Zaman" dalam bahasa Inggris pernah mencatat oplah sebesar 8.500 eksemplar. $^{38}$ Mereka juga menerbitkan majalah "Aksiyon", "Sizinti" dan "Fountain". Di samping itu, terbit beragam edisi "Zaman", seperti "Ailem" (Keluarga), "Turkuaz", "Kitap Zamani”, "Sektoreel” (dalam keuangan) dan "Genclik" (Pemuda).

Selain koran dan majalah, dakwah gerakan Nurcu juga bergerak dalam bidang telekomunikasi. Pada tahun 1980-an, sejalan dengan kebijakan liberalisasi oleh negara, gerakan Nurcu mendirikan stasiun televisi dan radio. Kelompok Yeni Nesil mendirikan Moral FM, sedangkan Gülen Movement mengoperasikan jaringan media yang meliputi empat saluran televisi: Samanyolu TV, Mehtap TV, Ebru TV dan Yumurcak TV. Kelompok Gülen juga mengoperasikan dua radio: Burc FM dan Dunya FM.

Media Nurcu di atas membidik ceruk usia tertentu, dari anakanak, anak muda, wanita yang umumnya ibu rumah tangga hingga kelompok urban terdidik. Media tersebut mengupas beragam topik dari perawatan anak, pendidikan psikologi, penanganan kesehatan, politik, perkawinan, lingkungan hidup, hingga sains dan teknologi. Media ini dipakai sebagai media dakwah yang menampilkan warna Islam yang modern dan berpikiran terbuka. Hal ini dimaksudkan untuk membantah wacana politik Kemalis yang mencitrakan Islam sebagai kelompok tradisional, mundur, terbelakang, anti-modern dan anti-demokrasi. Karena itu, jaringan media ini menjadi sarana dakwah efektif dalam menyuarakan warna Islam moderat, berkemajuan dan berorientasi pada demokrasi yang menggotong misi pelayanan bagi kemaslahatan masyarakat global (bizmet). Meminjam istilah Althusser, dengan mempunyai jaringan media ini gerakan Nurcu memiliki ideological apparatus. ${ }^{39}$

Turkish Islam and the Secular State: the Gülen Movement (New York: Syracuse University Press, 2003), 16-17.

37 https://en.wikipedia.org/wiki/Zaman_(newspaper), diakses pada 3 Mei 2015.

38 Angka ini masih diperdebatkan oleh banyak orang dengan tuduhan angka ini dibesar-besarkan. William Armstrong menuliskannya dalam blog pribadinya. https://armstrongwilliam.wordpress.com/2013/01/09/zamans-circulation-figuresthe-Gülen-effect/. Diakses 3 Mei 2015.

${ }^{39}$ Lihat Louis Althusser, Lenin and Philosophy and Other Essay (London: NLB, 1972). 
Media dakwah Nurcu lainnya adalah pendidikan, terutama pada Gülen Movement. Kelompok ini mendirikan sekolah tingkat menengah serta beberapa universitas. Pada tahun 1997, kelompok ini mengoperasikan 150 sekolah dan 150 dershane di Turki. ${ }^{40}$ Pada tahun 2005, kelompok ini sudah melebarkan sayap ke luar negeri dengan mengoperasikan 219 sekolah di luar negeri. Negara-negara tersebut meliputi: Amerika Serikat, Kanada, Jerman, Perancis, Inggris, Argentina, Nigeria, Ghana, Maroko, Sudan, Tanzania, Mali, Etiopia, Gambia, Kongo, Togo, Mozambik, Afrika Selatan, Australia, Filipina, Kamboja, Vietnam, Afghanistan, Pakistan, India, Iraq dan Burma. ${ }^{41}$ Saat ini Gülen Movement memiliki jaringan sekolah berjumlah tidak kurang dari 2.000 buah yang tersebar di seluruh dunia, termasuk Indonesia. ${ }^{42}$

Menariknya, sekolah tersebut tidak mengajarkan agama, justru memberi pengajaran pendidikan sekuler sebagaimana sekolah-sekolah di Turki pada umumnya. Sains menjadi fokus pengajaran pada sekolah tersebut. Hanya saja, sekolah Nurcu terlihat lebih berkualitas. Bahkan sekolah tersebut dinilai sebagai sekolah elite. Anak-anak Nurcu banyak bersekolah di sekolah tersebut karena orang tua ingin memberikan pendidikan yang terbaik bagi anak-anaknya. Cara ini adalah metode dakwah yang jitu. Pendirian sekolah yang berkualitas tersebut didasarkan pada pemikiran perlunya pendidikan yang bermutu bagi masyarakat dalam rangka menciptakan sumber daya manusia handal yang kelak menempati posisi strategis di Republik Turki dan dapat bersaing dengan kelompok Kemalis. ${ }^{43}$

Selama ini, orang yang mampu menembus kampus-kampus bergengsi berasal dari kalangan sekuler atau pengikut Kemalis karena mereka dididik di sekolah menengah yang berkualitas. Pada gilirannya mereka terserap dalam lapangan pekerjaan yang bergaji besar seperti perusahaan multinasional, perusahaan besar milik nasional, dan

\footnotetext{
40 Bekim Agai, “The Gülen Movement's Islamic Ethic of Education”, dalam M. Hakan Yavuz dan John L. Esposito (eds.), Turkish Islam and the Secular State: the Gülen Movement (New York: Syracuse University Press, 2003), 48.

41 Arslan, "Pious Science", 183.

42 Beberapa sekolah Nurcu di Indonesia, khususnya Gülen Movement, di antaranya adalah Pribadi BBS di Depok dan Bandung, Kharisma Bangsa BBS di Tangerang, Semesta BBS di Semarang, Hati BBS di Probolinggo (Jawa Timur), dan lain-lain.

${ }^{43}$ Fahri Caki, "New Social Classes and Movement in the Context of PoliticoEconomic Development in Contemporary Turkey" (Disertasi-The Temple University, 2001), 192.
} 
bekerja di pemerintahan sebagai pejabat tinggi. Mereka ini hanyalah segelintir orang yang dididik di kampus elite seperti Bogazici University, Istanbul Technical University, Bilkent University dan Middle East Technical University. Lulusan kampus bergengsi ini umumnya menguasai bahasa asing. Selain itu, untuk mendapatkan pekerjaan yang bergengsi tersebut dibutuhkan tidak saja pendidikan dari kampus elite, tetapi juga memiliki jejaring. Mereka umumnya berasal dari keluarga elite yang mampu membiayai pendidikannya di sekolah berkualitas dan memiliki jaringan di pusaran kekuasaan. ${ }^{44}$

Sementara itu, kelas menengah dari non-Kemalis berasal dari keluarga biasa. Sebagai lulusan kampus "pinggiran" dan lemahnya penguasaan bahasa asing menjadikan mereka hanya mampu bekerja di perusahaan kecil, atau di institusi negara yang bergaji kecil sebagai pegawai rendahan. Faktor lainnya adalah kurangnya jejaring sosial. Jejaring sosial yang mereka miliki terbatas. Karena bukan berasal dari keluarga papan atas, mereka tidak memiliki jaringan yang lebih tinggi. Mereka tertatih-tatih untuk mendapatkan akses karir yang lebih bagus. $^{45}$

Karena berangkat dari masyarakat periferi, mereka merupakan kelas sosial yang terkena dampak paling besar akibat ketimpangan ekonomi. Kebijakan liberalisasi ekonomi pada tahun 80 -an dan 90 -an mengakibatkan inflasi yang tinggi-hampir mendekati angka 100\%. Masa itu, gaji mereka harus berkejaran dengan inflasi yang terus membumbung tinggi. Jika sebelum tahun 1970-an, kelas terdidik terserap ke dalam lapangan pekerjaan di sektor birokrasi dan pemerintahan dengan gaji yang cukup besar dan gengsi sosial yang tinggi, namun sejak inflasi yang massif tersebut, gaji pegawai negeri menjadi relatif kecil dan kurang memadai, apalagi bagi pegawai rendahan. Menjadi pegawai negeri bukan lagi pekerjaan yang ideal. Akibatnya, terjadi pergeseran cara pandang. Sebagai kelas menengah, kaum terpelajar ini menyerbu sektor swasta yang menawarkan gaji lebih tinggi. Di sektor swasta ini, peluang kerjapun tersedia lebih luas. Singkatnya, selama periode liberalisasi ekonomi tersebut penguasa Kemalis gagal memuaskan kelas menengah. Kalangan muda terdidik ini kecewa dengan sistem yang ada. ${ }^{46}$

\footnotetext{
${ }^{44}$ Ibid., 196.

45 Ibid., 197-198.

${ }^{46}$ Ibid., 217.
} 
Faktor-faktor di atas kemudian menggerakkan kelompok periferi ini untuk menyokong gerakan oposisi terhadap penguasa Kemalis agar terbuka kesempatan yang lebih baik bagi kelasnya. Keberadaan mereka di daerah urban dengan kemudahan akses komunikasi pada gilirannya memudahkan terbangunnya aksi kelas tersebut. Dari aksi kelas ini, sejumlah tenaga terdidik bekerja sebagai penulis dan jurnalis yang kelak melahirkan sejumlah koran dan majalah Nurcu seperti "Zaman", "Yeni Asya", "Yeni Nesil", "Sizinti", "Zafer", dan lainlain—sebagaimana dijelaskan di atas. Di samping itu, mereka bekerja di lembaga-lembaga milik kelompok Nurcu, seperti lembaga pendidikan, penyiaran TV dan radio, perdagangan, yayasan, LSM dan kantor-kantor cabang Nurcu di luar negeri. ${ }^{47}$ Melalui sarana media tersebut, kaum terpelajar ini melakukan kerja dakwah untuk menjaga api gairah berislam masyarakat Turki tetap menyala meskipun dikepung westernisasi, materialisme dan ateisme. Dukungan media tersebut, pada gilirannya, memudahkan AKP yang baru berdiri memenangkan pemilu pada tahun 2002 dan $2007 . .^{48}$

Selain karena untuk berdakwah, bekerja pada lembaga Nurcu memberikan kemanfaatan kepada mereka. Salah satu manfaat tersebut adalah terbentuknya jaringan sosial. Solidaritas terbangun secara kuat di tengah komunitas ini. Solidaritas tersebut menghasilkan semacam jaminan sosial. Jika terjadi sesuatu pada dirinya, seorang pegiat Nurcu meyakini bahwa keluarga dan anak-anaknya akan ditopang sepenuhnya oleh kelompok ini. Bagi pengikut Nurcu yang bekerja di lembaga pemerintahan atau di sektor swasta milik kelompok sekuler terkadang menimbulkan permasalahan tersendiri. Seringkali mereka dilabeli sebagai fundamentalis. Sebagai pengikut Nurcu, mereka kerap mendapatkan perlakuan tidak adil dari atasan. Seringkali mereka tidak bisa menjalankan salat di tengah lingkungan sekuler seperti itu. Semua akan berbeda jika mereka bekerja di lingkungan gerakan Nurcu. Tidak saja mendapatkan ruang yang luas untuk menjalankan ibadah, mendapatkan ketenangan jiwa serta kepuasan spiritual, namun mereka bisa berkontribusi pada kerja dakwah gerakan Nurcu. ${ }^{49}$

\footnotetext{
47 Ibid., 200.

48 Ahmet T. Kuru, "Changing Perspectives on Islamism and Secularism in Turkey: The Gülen Movement and the AK Party", dalam International Conference Proceeding Muslim World in Transition: Contributions of the Gulen Movement, SOAS University of London, House of Lords and London School of Economics 25-27 Oktober (2007), 140-151.

${ }^{49}$ Caki, "New Social Classes", 218.
} 
Di mata pengikut Nurcu, lembaga di lingkungan Nurcu merupakan tempat ideal untuk bekerja dan mendapatkan penghidupan. Dengan demikian dapat dikatakan, salah satu penggerak keaktivan pegiat Nurcu didorong faktor finansial. Di tengah kelompok ini mereka mendapati pekerjaan dan gaji yang lumayan untuk menopang kebutuhan sehari-hari dibanding jika bekerja di lembaga pemerintahan atau swasta lain yang bergaji kecil. Gaji ini jauh lebih baik jika mengingat masih sulitnya akses untuk bekerja di sektor bergaji lebih besar seperti korporasi multinasional. Alasan ekonomi ini tidak dinafikan meskipun dorongan utama mereka bekerja di lembaga Nurcu sesungguhnya adalah untuk berdakwah.

Nurcu menyebarkan dakwah bukan dengan kekerasan, tetapi dengan persuasi dan akal. Dakwah Nurcu cenderung menghindari aksi konfrontatif. Penggunaan cara-cara damai membedakan Nurcu dengan gerakan Islam lainnya. Jika gerakan Islam politik cenderung mendengungkan wacana keagamaan yang kaku dan memperjuangkan perubahan fundamental sesegera mungkin, gerakan Nurcu memiliki metode dakwah yang fleksibel, lembut dan gradual. Nurcu beranggapan bahwa sebuah sistem sosial-politik akan serta-merta berubah menjadi sistem yang Islami jika sikap dan iman mayoritas masyarakat berkesesuaian dengan ajaran Islam.

Untuk menciptakan perubahan secara gradual tersebut, mesin organisasi harus selalu terbaharui. Gerakan Nurcu secara aktif melakukan pengkaderan. Ada beberapa pola perekrutan yang dilakukan oleh gerakan Nurcu: ${ }^{50}$ pertama, perekrutan para pelajar di sekolah-sekolah. Tidak sedikit kader Nurcu berhasil direkrut sejak mereka belajar di bangku sekolah. Proses rekrutmen berlangsung dalam kegiatan ekstra-kurikuler maupun kegiatan di luar kelas oleh "tutor" (pembina kegiatan). Kegiatan di luar kelas tersebut antara lain: olah-raga, piknik, mengundang tokoh intelektual Nurcu untuk ceramah, membaca Risale-i Nur, dan lain-lain. Kedua, rekrutmen melalui dershane. Warisan terpenting dari dakwah Nursi adalah dershane-secara literal berarti rumah belajar-yaitu tempat para pelajar bermukim dan mempelajari ajaran Nursi. Pada awalnya dershane berupa konsep sederhana. Pada saat Nursi masih hidup, dershane adalah tempat para pengikut awal Nursi mempelajari karya Nursi dan ajaran Islam. Dari awalnya hanya sebagai tempat untuk mengkaji Risale-i Nur, selanjutnya dershane sekaligus menjadi tempat

50 Ibid., 249. 
tinggal sejumlah pelajar. Karena itu kelompok Nurcu membuka dershane di sekitar sekolah-sekolah umum di hampir setiap kota. Seiring perjalanan waktu dershane berkembang pesat dan tersebar ke seluruh dunia. Di sebuah dershane yang penulis kunjungi di bilangan Ciputat, tidak jauh dari kampus UIN Syarif Hidayatullah Jakarta, berdiam sekitar 15 pelajar. Mereka datang dari berbagai daerah. Sewa rumah dibayar secara berpatungan. Mereka melakukan kegiatan bersama-sama: belajar, memasak, makan dan salat berjamaah. Selain itu, setiap sore mereka mengaji bersama untuk mempelajari Risale-i Nur. Umumnya dershane diperuntukkan bagi para pelajar, namun beberapa dershane diperuntukkan bagi orang umum. ${ }^{51}$

Selain itu, dershane berfungsi sebagai tempat bimbingan belajar bagi para siswa lulusan sekolah menengah yang ingin menembus bangku kuliah di universitas favorit. Karena itu, dershane menarik bagi kalangan menengah ke bawah yang tidak mampu mengikuti bimbingan belajar di lembaga-lembaga swasta. Mereka dibimbing oleh mahasiswa atau relawan yang membantu dalam bimbingan belajar untuk menembus universitas tersebut. Di tempat ini pula para siswa diperkenalkan ajaran Nurcu. Pembimbing di dershane ini disebut "abi" (kakak). Para pembimbing ini adalah sosok tauladan yang menjadi panutan siswa-siswa tersebut. Mereka memperlihatkan perilaku yang santun, akhlak terpuji, taat beragama, cerdas, pandai dan berilmu. Temsil (contoh) yang diperlihatkan oleh kakak pembimbing ini menjadi daya pikat bagi para siswa untuk selanjutnya memasuki pengkaderan gerakan Nurcu.

Mulai 1 September 2015 dershane secara resmi dilarang di Turki oleh pemerintahan AKP sebagai dampak dari perseteruan politik antara Fethullah Gülen dan Erdoğan. ${ }^{52}$ Perseteruan itu muncul, karena sebagai sebuah gerakan sosial dan dakwah, Nurcu memiliki karakteristik berbeda dari kelompok politik seperti Erdoğan dan AKP. ${ }^{53}$ Perbedaan pandangan idelogi dan politik dalam menyikapi sejumlah kasus pada akhirnya memicu gesekan antara Fethullah

51 Untuk mengetahui lebih jauh tentang dershane lihat Sammy Aziz, "An Examination of the Dershane Phenomenon: Observations of Its Embodiment in the US and Turkey" (Tesis--Hartford Seminary, Connecticut-USA, 2015).

52 BBC, “Turkey to Close Down 'Gülen’ Preparatory Schools”, 1 Maret 2014. http:/ /www.bbc.com/news/world-middle-east-26397755, diakses 3 Mei 2015.

53 Lihat Fait Muedini, "The Politics between the Justice and Development Party (AKP) and the Gülen Movement in Turkey: Issues of Human Rights and Rising Authoritarianism”, Muslim World Journal of Human Rights, Vol. 12, No. 1 (2015). 
Gülen-pendiri Gülen Movement, cabang dari gerakan Nurcudengan Erdoğan. ${ }^{54}$

Fenomena Nurcu yang paling menarik untuk dicermati adalah lahirnya orang kaya baru dari kalangan pengikut Nurcu. Menariknya karena beberapa hal: pertama, dana operasional Nurcu kebanyakan berasal dari kelompok kaya baru ini; dan kedua, karena memantik rasa penasaran penulis kenapa mereka bergabung dengan gerakan ini. Padahal kita tahu, dengan bergabung ke dalam gerakan Nurcu mereka akan kehilangan peluang bisnis yang lebih besar dibanding jika menjalin hubungan erat dengan penguasa. Mengapa mereka mengambil langkah berani yang cukup beresiko tersebut? Jawabannya adalah karena asal sosial, sikap kultural dan dorongan agama menjadi dasar pilihan tersebut.

Kemunculan kelompok kaya baru ini sejalan dengan kebangkitan ekonomi Turki yang dipicu kebijakan liberalisasi ekonomi oleh Turgut Özal, perdana menteri Turki pada tahun 1980-an dan menjadi presiden pada tahun 1990-an, yang berusaha membangun ekonomi pasar bebas, melepaskan perdagangan dengan luar negeri dan menghapus kontrol harga. Hasil kebijakan tersebut adalah bahwa saat ini ekonomi Turki meroket bersama-sama dengan sejumlah negara kaya baru yang kita kenal dengan istilah BRICTIn (Brazil, Rusia, India, China, Turki, Indonesia).

Menariknya, orang kaya baru ini muncul bukan di kota-kota besar Turki, tetapi justru muncul di kota-kota kecil di wilayah Anatolia yang selama ini jarang mendapat perhatian pemerintah. Mereka lahir di wilayah periferi yang jauh dari pusat kekuasaan. Mereka bukan tipe kelompok kaya yang menjadi hartawan berkat sokongan penguasa seperti kredit murah, bantuan modal, atau mendapat proyek dari pemerintah. Namun mereka menjadi kaya berkat kerja keras bergelut dengan bisnis yang tidak ada kaitannya dengan negara, seperti tekstil, pembuatan karpet, pakaian, sepatu, alat rumah tangga, penerbitan dan pengolahan kulit.

Kebanyakan orang kaya baru ini berasal dari wilayah timur Turki. Latar belakang orang kaya baru tersebut tidak jauh berbeda dari penduduk daerah Anatolia pada umumnya, terutama dalam budaya dan agama. Mereka memiliki hubungan yang erat dengan budaya lokal. Mereka berasal dari keluarga dengan warna keagamaan yang

${ }^{54}$ Lihat Svante E. Cornell, "Erdoğan's Looming Downfall”, Middle East Quarterly, Vol. 21, No. 2 (2014). 
kental. Mereka inilah yang pada akhirnya menjadi penyokong gerakan Nurcu. Dengan menjadi pengikut gerakan Nurcu, mereka menempatkan diri sebagai bagian dari mesin dakwah.

Dengan meminjam tesis Karl Marx tentang teori kelas, Fahri Caki menegaskan bahwa pembisnis dari kelompok orang kaya baru ini memendam kesadaran adanya perbedaan kelas sebagai "penduduk Anatolia yang religius" yang berbeda dari kelompok Kemalis. Cara hidup mereka berbeda dari kelompok Kemalis yang sekuler. Mereka dikenal sebagai orang yang taat beribadah, ketat dalam menjalankan ritual keagamaan, menghindari alkohol dan menjauhi kehidupan malam. Kebanyakan istri-istri mereka memakai jilbab dan menjadi ibu rumah tangga yang bertugas mengurus keluarga dan menjaga anak saja. ${ }^{55}$

Singkat kata, semenjak tahun 1980-an, Turki memasuki pasar bebas dan berorientasi pada ekspor. Fase baru ini melahirkan trasformasi ekonomi dan sosial yang sama sekali berbeda dengan kondisi sebelumnya. Salah satu transformasi tersebut adalah struktur ekonomi Turki. Jika selama ini kue ekonomi dinikmati oleh mereka yang mendapat perlakuan khusus dari negara, sejak perubahan kebijakan ekonomi muncul orang kaya baru yang berada di luar lingkaran kekuasaan. Kelompok kaya baru ini bersifat lokal, bergerak dalam bidang ekonomi yang berskala kecil dan menengah, serta beroperasi di pasar lokal. Kelompok pembisnis ini disebut "Anatolian Tigers". ${ }^{56}$ Selain menjadi penyokong utama gerakan dakwah Nurcu, orang kaya baru ini adalah pendorong kebangkitan ekonomi Turki sehingga kelak pada tahun 2015 menjadi negara terkaya ke-17.

Di samping itu, tidak sedikit masyarakat biasa di Turki akhirnya bisa menikmati bangku kuliah di kampus-kampus elite berkat dershane dan sekolah-sekolah berkualitas milik gerakan Nurcu. Tidak sedikit dari mereka akhirnya menjadi tenaga profesional di bidang teknik, manajer, dokter dan bidang lainnya. Kelompok kelas menengah terdidik ini mewakili kebangkitan umat Islam Turki yang terpelajar dan saleh dalam ibadah. Pada diri mereka tergambar sosok

\footnotetext{
55 Caki, "New Social Classes", 171.

56 Lihat Ömer Demir, Mustafa Acar dan Metin Toprak, "Anatolian Tigers or Islamic Capital: Prospects and Challenges", Middle Eastern Studies, Vol. 40, No. 6 (2004), 166-188; Lihat juga Basak Ozoral, "Economic Engagement of Religious Ethics in a Global Economy: The Rise of Islamic Capital in Central Anatolia as a New Economic Power, 1980_Present" (Disertasi-McGill University, MontrealCanada, 2011);
} 
anggota gerakan Nurcu par excellence: yaitu sosok Muslim saleh yang tidak mempermasalahkan modernitas dan tidak menentang modernitas dalam bidang sosial, ekonomi dan politik. Nurcu mendukung demokratisasi dan sekularisasi. Mereka bahkan mendukung integrasi Turki dengan dunia Barat dan menyokong ekonomi pasar bebas, swastanisasi dan masuknya aliran dana dari modal asing. Nurcu adalah kelompok yang merekonsiliasi antara modernitas dan agama. Sebagai akibat meluasnya kesempatan mendapatkan pendidikan tinggi pada gilirannya memperkuat tumbuhnya barisan kelas menengah yang memperkuat bangunan negara Turki saat ini.

\section{Penutup}

Nurcu adalah gerakan Islam moderat yang melakukan kerja dakwah di Turki modern. Gerakan ini memainkan peran penting dalam kebangkitan Islam di negara Turki setelah sekian lama di bawah rezim Kemalis yang melakukan westernisasi besar-besaran. Nurcu adalah gerakan dakwah Islam yang muncul sebagai anti-hegemoni dari kelompok sosial yang dirugikan akibat percepatan transformasi dalam bidang sosial, ekonomi dan kultural seperti urbanisasi, industrialisasi, westernisasi dan kesenjangan pembagian kue ekonomi serta hegemoni rezim Kemalis. Pada tahun 1980-an, Turki masuk ke dalam arus ekonomi dunia sebagai bagian dari proyek modernisasinya dengan menumbuhkan industrialisasi. Kebijakan ini melahirkan kelompok orang kaya baru dari kalangan masyarakat Muslim "pinggiran". Jika di kemudian hari, di saat Erdoğan berkuasa, ekonomi Turki berkembang pesat hingga menembus angka 17 sebagai negara kaya dunia, semua itu tidak lain adalah berkat kemunculan orang kaya baru dari pengikut Nurcu yang dikenal sebagai "Anatolian Tigers".

Nurcu bukanlah sekedar gerakan Islam, tetapi merupakan sebuah gerakan dakwah dengan warna Islam yang progresif dengan tujuan mendefinisi ulang aspek-aspek modernisasi di Turki. Nurcu berusaha mengawinkan antara modernitas dan agama. Pendidikan dipilih sebagai metode untuk perkawinan tersebut. Modernisasi menjadi puncak tujuan mereka, yaitu modernisasi yang tidak mengorbankan budaya bangsa yang terbentuk di atas pondasi Islam dan sejarah budaya warisan Kesultanan Ottoman. Sejak kelahirannya, gerakan Nurcu menjaga api Islam tetap menyala di Turki di tengah arus westernisasi. Jika gegap gempita berislam rakyat Turki tampak sangat 
mencolok saat ini, hal tersebut sebagian merupakan hasil kerja dakwah gerakan Nurcu, bukan semata-mata karena Erdoğan dan AKP saja.

\section{Daftar Rujukan}

Agai, Bekim. "The Gülen Movement's Islamic Ethic of Education”, dalam M. Hakan Yavuz dan John L. Esposito (eds.). Turkish Islam and the Secular State: the Gülen Movement. New York: Syracuse University Press, 2003.

Algar, Hamid. "Said Nursi and the Risale-i Nur. An Aspect of Islam in Contemporary Turkey". Islamic Perspective-Studies in Honor of Sayyid Abul Ala Mawdudi. Leicester: t.tp., 1979

Althusser, Louis. Lenin and Pbilosophy and Other Essay. London: NLB, 1972.

Andrews, Mathew. "Building Institutional Trust in Germany: Relative Success of the Gülen and Milli Gorus", Turkish Studies, Vol. 12, No. 3, September 2011.

Arslan, Berna. "Pious Science: The Gülen Community and the Making of a Conservative Modernity in Turkey". Disertasi--the University of California, Santa Cruz, 2009.

Aziz, Sammy. "An Examination of the Dershane Phenomenon: Observations of Its Embodiment in the US and Turkey". Tesis-Hartford Seminary, Connecticut-USA, 2015.

Caki, Fahri. "New Social Classes and Movement in the Context of Politico-Economic Development in Contemporary Turkey". Disertasi-The Temple University, 2001.

Cornell, Svante E. "Erdoğan's Looming Downfall", Middle East Quarterly, Vol. 21, No. 2, 2014.

Demir, Ömer., Acar, Mustafa., dan Toprak, Metin. "Anatolian Tigers or Islamic Capital: Prospects and Challenges", Middle Eastern Studies, Vol. 40, No. 6, 2004.

Hidayat, Nuim. "Islamisasi Partai Islam: Pelajaran dari Erdogan", Hidayatullah, 29 Maret 2014.

Kuru, Ahmet T. "Changing Perspectives on Islamism and Secularism in Turkey: The Gülen Movement and the AK Party", dalam International Conference Proceeding —Muslim World in Transition: Contributions of the Gulen Movement, SOAS University of London, House of Lords and London School of Economics 25-27 Oktober, 2007.

Kuru, Zeynep Akbulut dan Kuru, Ahmet T. “Apolitical Interpretation of Islam: Said Nursi's Faith-Based Activism in Comparison with 
Political Islamism and Sufism", Islam and Christian-Muslim Relations, Vol. 19, No. 1, 2008.

Lewis, Bernard. The Emergence of Modern Turkey. London: Oxford University Press, 1961.

Mardin, Serif. Religion and Social Change in Modern Turkey: The Case of Bediuzzaman Said Nursi. Albany: SUNNI Press, 1989.

Muedini, Fait. "The Politics between the Justice and Development Party (AKP) and the Gülen Movement in Turkey: Issues of Human Rights and Rising Authoritarianism", Muslim World Journal of Human Rights, Vol. 12, No. 1, 2015.

Olson, Robert. The Emergence of Kurdish Nationalism and the Sheikh Said Rebellion: 1880-1925. Austin: University of Texas Press, 1989.

Ozoral, Basak. "Economic Engagement of Religious Ethics in a

Global Economy: The Rise of Islamic Capital in Central Anatolia as a New Economic Power, 1980-Present". Disertasi-McGill University, Montreal-Canada, 2011.

Sakallioglu, Umit Cizre. "Parameters and Strategies of Islam-State Interaction in Republican Turkey", International Journal of Middle Eastern Studies, 28, 1996.

Turner, Colin. "I Seek Refuge in God from Satan and Politics..." A Nursian Perspective on the Role of Religion in State and Society", Bediuzzaman Said Nursi, t.th., http://www.bediuzzamansaid nursi.org/en/icerik/i-seek-refuge-god-satan-and-politics-nursianperspective-role-religion-state-and-society. Diakses tanggal 22 April 2015.

Vahide, Sukran. "The Life and Times of Bediuzzaman Said Nursi", The Muslim World, Vol. LXXXIX, No. 3-4, 1999.

----. "Toward an Intellectual Biography of Said Nursi", dalam Ibrahim M. Abu Rabi (ed.), Islam at the Crossroads: On the Thought and Life of Bediuzzaman Said Nursi. Albany: State University of New York Press, 2003.

Yavuz, Hakan. "The Gülen movement: The Turkish puritans" dalam Hakan Yavuz and John L. Esposito (eds.) Turkish Islam and the Secular State: the Gülen Movement. New York: Syracuse University Press, 2003.

-----. "Towards an Islamic Liberalism?: The Nurcu Movement and Fethullah Gülen”, Middle East Journal, Vol. 53, No. 4, 1999. 
Yildiz, Ahmet. "Politico-Religious Discourse of Political Islam in Turkey: The Parties of National Outlook". The Muslim World, Vol. 93, April 2003.

Zubaidi, Sujiat. "Tafsir Kontemporer Bediuzzaman Said Nursi dalam Risale-i Nur, Studi Konstruk Epistemologi”. Disertasi--UIN Sunan Ampel Surabaya, 2015.

BBC. “Turkey to Close Down 'Gülen' Preparatory Schools”, 1 Maret 2014. http://www.bbc.com/news/world-middle-east-26397755, diakses 3 Mei 2015.

https://armstrongwilliam.wordpress.com/2013/01/09/zamans-circulation-figures-the-Gülen-effect/. Diakses 3 Mei 2015.

https://en.wikipedia.org/wiki/List_of_countries_by_GDP_(PPP);

lihat juga, https://knoema.com/nwnfkne/world-gdp-ranking2015-data-and-charts. Diakses pada 3 Mei 2015.

https://en.wikipedia.org/wiki/Zaman_(newspaper), diakses pada 3 Mei 2015. 